\title{
Konservasi Nilai Budaya Indonesia melalui Bahasa Daerah
}

\author{
Isti Purwaningtyas dan Esti Junining*)
}

\begin{abstract}
Abstrak
Pendidikan seni budaya, termasuk pendidikan budi pekerti, merupakan upaya paling mendasar yang harus diterapkan kepada anak-anak generasi bangsa, karena tanpa mengenal budaya Indonesia, maka pertumbuhan generasi akan kacau di masa datang. Efek dari hal ini adalah timbulnya demoralisasi atau kemerosotan moral di masyarakat. Misalnya, dalam masyarakat Jawa, kehalusan bertutur kata yang tercermin dalam stratifikasi bahasa Jawa sudah mengalami erosi berat. Anak-anak muda tidak lagi mau dan mampu berbahasa krama dengan orang tuanya dan dengan orang lain yang lebih tua sebagai wujud adanya rasa hormat. Apalagi pada era globalisasi saat ini, identitas budaya pribumi (lokal) dan budaya nasional makin musnah, tergerus oleh budaya global atau kultural dunia barat. Kecintaan budaya lokal dan nasional sangat penting demi kemajuan bangsa. Akar dan keberagaman budaya lokal dan nasional tersebut akan mampu mengikis masuknya budaya global yang negatif. Tidak hanya itu, perspektif budaya lokal akan mampu menyatukan komponen bangsa menuju keberhasilan pembangunan. Perangkat dan pengaruh globalisasi terhadap budaya dan seni masyarakat akan memudarkan aktivitas seni dan budaya lokal. Seni budaya lokal dan nasional yang sangat positif sangat perlu diterapkan menjadi materi pendidikan dalam proses belajar mengajar di sekolah. Oleh karena itu, upaya peningkatan dalam menanamkan kecintaan terhadap budaya daerah dan nasional diterapkan di sekolah dengan berbagai kompetisi, kreativitas lomba budaya daerah terutama melalui lembaga-lembaga pendidikan formal dan non formal. Agar pemilik dan penutur asli bahasa daerah sadar tentang begitu besar dan pentingnya fungsi bahasa daerah, perlu diupayakan peningkatan mutu pemakaian bahasa daerah, mencakup upaya meningkatkan sikap, pengetahuan, dan ketrampilan berbahasa daerah melalui jalur formal - pendidikan dan pengajaran di sekolah dan jalur informal--dengan memfungsikan bahasa daerah dalam kehidupan masyarakat sehari-hari.
\end{abstract}

Kata kunci: konservasi, budaya nasional, bahasa daerah.

\footnotetext{
${ }^{*}$ Pengajar pada Fakultas Ilmu Budaya, Universitas Brawijaya
} 


\section{Pengantar}

Indonesia yang terbentang dari Sabang sampai Merauke, dari Aceh hingga Papua diperkaya oleh beratus suku, bahasa dan budaya. Indonesia hadir dengan selumbung kekayaan bahasa dan budaya. Summer Institute of Linguistics (2001) dalam The Languages of Indonesia menyebutkan bahwa paling sedikit terdapat 726 bahasa-bahasa di Indonesia. Masyarakat Indonesia adalah masyarakat yang serbamulti: multibahasa, multiagama dan multietnis dengan menggunakan satu bahasa nasional, yaitu bahasa Indonesia telah merekatkan semua kalangan dan menerima semua perbedaan kebahasaan dan kebudayaan daerah sebagai kekayaan kebudayaan nasional.

Sementara itu, tatkala menyebut etnis tersebut, melekat di dalamnya adalah bahasa-bahasa daerah yang digunakan oleh setiap etnis tersebut. Artinya, tidak mungkin mengindentifikasi adanya etnis tersebut tanpa bahasa etnis itu sendiri. Oleh sebab itu, bahasa daerah menjadi identitas yang menandai keberadaan etnis tersebut yang ada di Indonesia. Karena jelas, etnis-etnis itu sendirilah menjadi pengisi konkret keindonesiaan dan, secara kultural linguis, keindonesiaan ada di bahasabahasa daerah di negara ini (Mahsun, 2008).

Upaya untuk mengangkat budaya dan bahasa daerah ke dalam kosakata bahasa nasional diharapkan sebagai langkah nyata pemeliharaan bahasa-bahasa daerah. Dari sanalah kita berpijak bahwa keberagaman tercipta sebagai kekayaan bukan sebaliknya. Salah satu keputusan yang bersifat politis yang dihasilkan Seminar Politik Bahasa tahun 2000 adalah ditentukan fungsi bahasa daerah sebagai: (a) lambang kebanggaan daerah, (b) lambang identitas daerah, (c) alat perhubungan di dalam keluarga dan masyarakat daerah, (d) sarana pendukung budaya daerah dan bahasa Indonesia, (e) pendukung sastra daerah dan sastra Indonesia. 
Selain itu, dalam hubungannya dengan bahasa Indonesia, bahasa daerah berfungsi sebagai: (a) pendukung bahasa nasional, (b) bahasa pengantar di sekolah dasar di daerah tertentu pada tingkat permulaan untuk memperlancar pengajaran bahasa Indonesia dan mata pelajaran lain, dan (c) sumber kebahasaan untuk memperkaya bahasa Indonesia, serta (d) dalam keadaan tertentu dapat berfungsi sebagai pelengkap bahasa Indonesia di dalam penyelenggaraan pemerintahan pada tingkat daerah (Alwi dan Dendy Soegono (2000) dalam Mahsun (2004).

Perlindungan terhadap eksistensi bahasa daerah telah menjadi bagian upaya badan dunia PBB dan UNESCO dalam menyelamatkan bahasa-bahasa lokal dunia. Demikian juga dengan bahasa-bahasa daerah yang ada di Indonesia. Meskipun telah ada jaminan keberlangsungan bahasa daerah sebagai bagian dari keberagaman kebudayaan Indonesia dalam UUD 1945, sesuai dengan amanat pasal 36 UUD 1945 bahwa bahasa daerah adalah satu unsur pemerkaya bahasa nasional, bahasa Indonesia, dan eksistensinya dilindungi oleh negara, dan dimasukkannya bahasa daerah dalam muatan lokal kurikulum sekolah KTSP, semua itu belum menjamin keberlangsungan eksitensi bahasa daerah untuk hidup di tengah bahasa persatuan Indonesia dan arus deras pengaruh negatif globalisasi terhadap tata bahasa sehari-hari dan bahasa asing yang mulai banyak digunakan.

\section{Pembahasan}

\subsection{Kondisi Bahasa Daerah di Era Global}

Suryanyahu, "Sikap Bahasa dan Pilihan Bahasa Penutur Jati Bahasa Dayak Ngaju di Kota Palangka Raya, laporan penelitian pada Balai Bahasa Provinsi Kalimantan Tengah, 2005) menyatakan bahwa sikap bahasa masyarakat penutur jati bahasa Dayak Ngaju cenderung 
negatif dan tidak lagi memandang bahasa ibunya sebagai sebuah lambang identitas dan kebanggaan.

Bahasa Jawa adalah bahasa dengan jumlah penutur yang paling besar di Indonesia dan masih ditambah lagi dengan mereka yang tinggal di belahan bumi yang lain seperti di Afrika Selatan dan Suriname. Bagaimana kondisi bahasa, sastra, dan aksara Jawa sekarang? Kondisi bahasa Jawa dewasa ini sesuai dengan makalah yang disajikan pada Kongres Bahasa Jawa III di Yogyakarta pada bulan Juli 2001 yang berjudul "Dampak Kealpaan Penutur Bahasa Jawa Terhadap Perilaku Bangsa”, dan pada Kongres Linguistik Nasional Masyarakat Linguistik Indonesia di Denpasar, Bali bulan Juli 2002, dengan judul "Kealpaan Terhadap Penghormatan dan Pemeliharaan Bahasa Daerah Pengemban Kebudayaan Nasional.” menyatakan bahwa bahasa Jawa sekarang ini telah mengalami penurunan secara kualitas maupun kuantitas. Secara kualitas, stratifikasi bahasa Jawa yang ada — krama inggil, krama andhap, krama lugu, ngoko ndhap, dan ngoko lugu-yang sudah tertata secara rapi dan indah itu tidak dipergunakan sebagaimana mestinya dalam berbahasa oleh sebagian besar penutur asli bahasa Jawa. Kesalahan pemilihan leksikon, sintaksis, dan semantis dalam bertutur kata sering terjadi pada kalangan penutur bahasa Jawa. Secara kuantitas, penggunaan bahasa Jawa krama inggil dan karma andhap frekuensinya sangat kecil, dalam kalangan keluarga dan masyarakat untuk urusan formal maupun non-formal, terutama pada kalangan generasi muda.

\subsubsection{Manfaat Mempertahankan dan Mengembangkan Bahasa dan Sastra Daerah}

Pemahaman budaya suatu bangsa dapat dilakukan secara mendalam jika pemahaman itu dilakukan atas dasar perspektif budaya 
bangsa itu sendiri, bukan dari perspektif budaya asing. Demikian pula halnya dengan pemahaman budaya, bahasa dan sastra daerah. Pemahaman budaya, bahasa dan sastra daerah dapat dicapai kedalamannya, apabila kita mampu melihatnya dari perspektif budaya, bahasa, sastra, dan aksara daerah itu sendiri. Apabila pemilik dan penutur asli bahasa daerah sadar bahwa begitu besar dan pentingnya fungsi bahasa daerah, perlu diupayakan peningkatan mutu pemakaian bahasa daerah, mencakup upaya meningkatkan sikap, pengetahuan, dan keterampilan berbahasa daerah melalui jalur formal-pendidikan dan pengajaran di sekolah dan jalur informal--dengan memfungsikan bahasa daerah dalam kehidupan masyarakat sehari-hari.

Pembinaan sastra daerah juga perlu didahului dengan penanaman kesadaran kepada seluruh rakyat Indonesia dan pemilik sastra daerah bahwa sastra daerah merupakan bukti historis masyarakat daerah. Sehubungan dengan itu, sastra daerah sebagai salah satu bagian dari sastra Indonesia berkedudukan sebagai wahana ekspresi budaya Indonesia, yang di dalamnya terekam pengalaman etika, estetika, moral, agama, dan sosial masyarakat daerah. Dalam kedudukannya sebagai wahana ekspresi budaya, sastra daerah memiliki fungsi sebagai perekam kebudayaan daerah dan pemelihara, pemupuk, dan penumbuh solidaritas daerah

\subsubsection{Konservasi Budaya Nasional dengan Bahasa Daerah}

Pembelajaran unsur etika dalam pembelajaran bahasa daerah sangat penting bagi pendidikan usia dini, terutama bagi generasi sekarang yang telah korosif oleh pengaruh budaya dari luar terutama dalam bentuk pembelajaran budaya, etika, dan moralitas. Hal ini dituangkan dalam bentuk (1) pembelajaran bahasa daerah sebagai sarana untuk belajar 
moralitas, filosofis, dan akseptabilitas sosial; 2. penyediaan infrasruktur bahasa (daerah) standar yang mapan (yang diseminarkan dan dilokakaryakan pada daerah masing-masing), bahan ajar yang sesuai GBPP, analisis kebutuhan dan kondisi daerah (yang dilokakaryakan dan diseminarkan) beserta kuantitas dan kualitas tenaga kependidikan untuk itu pada tingkat pendidikan formal (TK, SD) dan sektor nonformal, dan (3) pembinaan pembelajaran bahasa daerah dalam bentuk pelatihan, seminar, dan lomba-lomba yang menumbuhkan kecintaan terhadap budaya nasional melalui bahasa daerah.

Hal serupa telah dilakukan oleh Pemerintah Kota melalui Dinas Pendidikan dan Kebudayaaan Kota Batu, yang menerapkan nilai-nilai luhur budi pekerti di Sekolah dengan melaksanakan program Sedinten Basa Jawi. Bahasa Jawa mengandung nilai-nilai budaya dan adat istiadat masyarakat Jawa yang sangat menghargai perbedaan dan menghormati tata krama dalam kehidupan bermasyarakat. Seperti, terdapat tatanan Bahasa Jawa Ngoko (kasar/biasa), Krama (halus/sopan) dan Krama Inggil (sangat sopan/sangat halus). Strata dalam berkomunikasi dalam Bahasa Jawa tersebut mengandung unsur pendidikan budi pekerti dengan menghargai perbedaan dan menghormati seseorang misalnya kepada orang tua, guru, atasan, kawan, dan sesuai asas norma kehidupan bermasyarakat Jawa pada umumnya. Misalnya, penggunaan unsur kata "Panjenengan" (Krama Inggil) untuk menghormati orang yang dianggap lebih tua, dan itu harus sering dipakai apabila menyapa sesorang yang lebih senior atau untuk para pejabat (Yang Dipertuan Agung). Namun begitu, unsur kata "Sampeyan" yang artinya sama (Krama), Koen atau Kowe (Ngoko), model Bahasa Jawa Timuran, tetap menjadi unsur komunikasi sehari-hari di masyarakat. Bedanya, "Panjenengan" itu lazim digunakan menghormati orang dengan sangat halus (Jawa Mataraman) 
dan "Koen" sifatnya datar seperti dalam komunikasi kehidupan di masyarakat Jawa Timuran (Dialek Jawa Timur). Dialek bahasa Daerah di Jawa Timur, menurut Tanto, juga perlu diajarkan kepada siswa, di samping mengajarkan bahasa daerah standar, agar siswa mengetahui bahwa bahasa daerah yang dipakai komunikasi adalah bahasa standar lengkap dengan perangkat undha usuk-nya. Akhirnya, siswa tahu dengan siapa dia berbicara, dimana tempat berbahasa, dan dalam situasi apa dia memakai bahasa Daerah/Jawa.

Program ini dilaksanakan di jenjang pendidikan TK dan SD di seluruh Kota Batu Jatim. Pada 2002, Pemkot Batu dalam program ini berusaha merestrukturisasi mata pelajaran Basa Jawi sebagai kekayaan budaya dan mapel wajib yang harus diajarkan di jenjang pendidikan dasar, TK dan SD. Apalagi, dengan penerapan Kurikulum Tingkat Satuan Pendidikan (KTSP) pada 2006, fungsi dan peran Basa Jawi sangat vital, guna meningkatkan kecintaan terhadap budaya daerah serta ngangsu kawruh terhadap nilai-nilai luhur budaya Jawa yang menyatu dalam pendidikan budi pekerti yang telah ada di masyarakat Jawa. Oleh karena itu, sebagai sinergi kelestarian dan pengembangan, Dinas P dan K Kota Batu, menanggulangi lunturnya bahasa daerah dan sastra Jawa di lingkungan remaja, sejak beberapa tahun lalu menerapkan program Sedinten Basa Jawi di TK/RA dan SD/MI. Pelaksanaan Sedinten Basa Jawi ini adalah realisasi kebijakan Pemkot Batu, dalam rangka pelestarian dan pengembangan bahasa dan sastra Daerah yang merupakan bagian dari Kebudayaan Indonesia.

Dalam penerapan Bahasa Daerah/Basa Jawi di sekolah di Batu, diakui adanya berbagai kendala. Pertama, belum ada guru khusus bidang bahasa dan sastra jawa di Kota Batu. Dalam pengajaran Basa Jawi di sekolah hanya dibimbing oleh guru kelas, padahal guru kelas tersebut 
sangat terbatas tentang ilmu bahasa dan satra Jawanya. Kedua, belum adanya buku panduan khusus tentang materi dan sistem pengajaran Basa Jawi di Sekolah di Batu. Hal ini sangat menyulitkan para guru dalam proses belajar mengajar. Maka itu, sangat diperlukan pelatihan-pelatihan, workshop untuk menyusun sebuah buku panduan khusus tentang pengajaran Basa Jawi di Kota Batu. Dan ini otomatis, diperlukan anggaran khusus pengembangan bahasa yang lebih besar. Ketiga, perlu peningkatan efektifitas berbagai kegiatan dan lomba-lomba untuk pengembangan Basa Jawi, seperti Bazar Seni termasuk lomba Macapat, Lomba nulis Aksara Jawa, Lomba Pidato Bahasa Jawa dan sebagainya.

Seni budaya lokal dan nasional yang sangat positif sangat perlu diterapkan menjadi materi pendidikan dalam proses belajar mengajar di sekolah. Karena inilah, upaya peningkatan dalam menanamkan kecintaan terhadap budaya daerah dan nasional diterapkan di sekolah dengan berbagai kompetisi, kreativitas lomba budaya daerah terutama melalui lembaga-lembaga pendidikan formal dan non formal.

Di Kota Batu, kecintaan terhadap budaya daerah dan nasional dilaksanakan melalui berbagai upaya. Pertama, seni budaya dimasukkan dalam pendidikan di sekolah dengan karakteristik mata pelajaran seni dan budaya. Kedua, fasilitasi Penyelenggaraan Festival Budaya Daerah (Lomba Budaya Adikara tingkat propinsi). Ketiga, pemberian dukungan penghargaan dan kerjasama di bidang budaya. Keempat, untuk meningkatkan kecintaan terhadap budaya daerah, Dinas P dan K Kota Batu, melaksanakan seminar dalam rangka revitalisasi dan reaktualisasi budaya lokal. Kelima, upaya Dinas untuk mengembangkan budaya lokal dan nasional adalah dengan mengembangkan minat dan budaya baca di kalangan siswa. Keenam, penyelenggaraan lomba-lomba seni budaya di tingkat daerah/kota. Upaya peningkatan kecintaan terhadap budaya 
daerah dan nasional dengan fasilitasi Penyelenggaraan Festival Budaya Daerah (Lomba Budaya Adikara tingkat Propinsi). Dinas P dan K Kota Batu, bekerja sama dengan seniman menyelenggarakan penyeleksian para nominator seni dan sastra di kalangan siswa untuk dikirim ke festival budaya daerah Adikara di tingkat propinsi.

\section{Penutup}

\subsection{Simpulan}

Pengajaran bahasa dan sastra selalu dipersepsikan identik dengan tujuan pembentukan kepribadian dan identitas bangsa. Fungsi kultural agar dapat digali dan ditanamkan kembali nilai-nilai budaya sebagai upaya untuk membangun identitas dan menanamkan local genius. Pada fungsi bahasa sebagai alat komunikasi diarahkan agar siswa dapat berbahasa daerah dengan baik dan benar disamping juga menerapkan nilai kearifan lokal yang tercermin lewat penerapan unggah-ungguhing basa.

\section{Daftar Pustaka}

Program Sedinten Basa Jawi Menjunjung Nilai Budi Pekerti. 2008. http://pemkotbatu.go.id/ina/index.php?mg=home\&id=283\&kd=1 $3 \&$ did=detail

http://pusatbahasa.depdiknas.go.id

Mahsun,dkk. Keindonesiaan di Bahasa Daerah. http://dunia.pelajarislam.or.id/dunia.pii/pendidikan/keindonesiaan-di-bahasadaerah.html

Mengembangkan kecintaan terhadap budaya daerah dan nasional. 2008. http://pemkotbatu.go.id/ina/index.php?mg=home\&id=283\&kd=1 $2 \&$ did=detail 
Nyahu, anthony. Pembelajaran bahasa daerah dalam kerangka pemahaman lintas budaya masyarakat multikultural: strategi preventif terhadap kondisi disharmoni dan manajemen pasca konflik di kalimantan tengah. 2008.

Wahab, Abdul. 2001. "Dampak Kealpaan Penutur Bahasa Jawa terhadap Perilaku Bangsa." Kongres Bahasa Jawa III di Yogyakarta, Juli 2001.

Wahab, Abdul. 2002. "Kealpaan terhadap Penghormatan dan Pemeliharaan Bahasa Daerah Pengemban Kebudayaan Nasional." Kongres Masyarakat Linguistik Indonesia di Denpasar-Bali, Juli 2002. 